\title{
Cadmium-Induced Changes in Germination, Seedlings Growth, and DNA Fingerprinting of in vitro Grown Cichorium pumilum Jacq.
}

\author{
Wesam Al Khateeb ${ }^{1}$ \\ ${ }^{1}$ Department of Biological Sciences, Yarmouk University, Jordan \\ Correspondence: Wesam Al Khateeb, Department of Biological Sciences, Yarmouk University, Irbid, Jordan. Tel: \\ 962-2721-1111 ext 2822. E-mail: wesamyu@gmail.com
}

Received: October 24, 2013 Accepted: November 27, 2013 Online Published: November 29, 2013

doi:10.5539/ijb.v6n1p65

URL: http://dx.doi.org/10.5539/ijb.v6n1p65

\begin{abstract}
The aim of this study was to assess the effect of $\mathrm{Cd}^{2+}$ on germination, growth, proline content, lipid peroxidation, and DNA fingerprinting of in vitro grown Cichorium pumilum. Results showed that seed germination was highly inhibited by cadmium (down to $47 \%$ at $1600 \mu \mathrm{M} \mathrm{CdCl}_{2}$ ). In addition, root and shoot growth showed significant decreases in response to $\mathrm{CdCl}_{2}$ level. Analysis of proline content and lipid peroxidation showed that with increasing $\mathrm{CdCl}_{2}$ levels in the growing medium, the amount of proline accumulation and lipid peroxidation increased gradually. Total chlorophyll content was found to increase only at higher tested levels of $\mathrm{Cd}^{2+}(800$ and $1600 \mu \mathrm{M})$. The results also show that $\mathrm{Cd}^{2+}$ inhibits callus growth at different levels starting from $50 \mu \mathrm{M} \mathrm{CdCl}_{2}$ compared with the control in the callus growth experiment. Callus growth ceased completely at $200 \mu \mathrm{M} \mathrm{CdCl}_{2}$ and above. Random amplified polymorphic DNA (RAPD) analysis showed DNA alterations in $\mathrm{Cd}^{2+}$-treated $C$. pumilum microshoots compared with the control. The results of this experiment showed that $\mathrm{Cd}^{2+}$ stress affects several physiological, biochemical, and molecular processes in C. pumilum.
\end{abstract}

Keywords: Cadmium, proline, lipid peroxidation, fingerprinting, Cichorium pumilum

\section{Introduction}

Chicory (Cichorium pumilum Jacq., Asteraceae), is a bushy perennial herb with blue or lavender flowers which grows as a wild plant on roadsides. Chicory is also known as blue sailors, endive, radicchio, French endive, red endive, sugarloaf, witloof, elit, and coffeeweed. It is a culinary and medicinal plant grown worldwide. In the Middle East, its leaves are widely used in salads after being blanched, as the unblanched leaves taste bitter. In Europe, the root is eaten like a vegetable after being boiled, or it can be roasted then ground for use as a coffee substitute (Robert et al., 2008). Al Khateeb et al. (2012) showed that $C$. pumilum methanolic extracts have high levels of phenolic compounds and showed very strong antioxidant properties. Moreover, they found that methanol and ethanol extracts obtained from $C$. pumilum have antimicrobial effects on 10 different bacterial species.

In the last few decades, a dramatic increase in the contamination of the environment, (including soil, air, and water) has been observed. It appears that anthropogenic activities are the main source of the pollution that is causing the environment contamination (Gratao et al., 2005). Recently, it has been shown that large areas of land have been contaminated with heavy metals as a result of urban activities, agricultural practices, and industry.

Heavy metals are defined as the group of elements that have specific weights higher than about $5{\mathrm{~g} \times \mathrm{cm}^{-3}}^{-3}$ A number of them $(\mathrm{Co}, \mathrm{Fe}, \mathrm{Mn}, \mathrm{Mo}, \mathrm{Ni}, \mathrm{Zn}, \mathrm{Cu})$ are essential micronutrients which are required for normal growth and for many metabolic processes in plants. Metals which are considered nonessential ( $\mathrm{Pb}, \mathrm{Cd}, \mathrm{Cr}, \mathrm{Hg}$, etc.) are potentially highly toxic for plants (Sebastiani et al., 2004). Contamination of soil by heavy metals is a global ecological problem because heavy metals are included in the main category of environmental pollutants which can remain in the environment for long periods. Their accumulation is potentially hazardous to humans, animals, and plants (Benavides et al., 2005).

Agricultural soil contamination can severely affect humans, both directly (through the food web) and indirectly (by damaging environmental health) (Nriagu, 1990). For plants, heavy metals are phytotoxic, causing growth inhibition and eventually plant death through mechanisms that are still not completely understood (Romero-Puertas et al., 1999). The toxic effect of increasing cadmium (Cd) concentration in the environment has 
become a major environmental concern (Shriarastava \& Singh, 1989). Cadmium accumulation in soils may come from various sources: from air pollutants or through applications of commercial fertilizers, sewage sludge, manure, and lime (Kidd et al., 2007). Also, industrial effluents may contain a wide variety of pollutants depending on the industries involved (Iribar et al., 2000). Cd is generally present in soil as free ions or in different soluble forms, and its mobility is affected by $\mathrm{pH}$ and the presence of chelating substances and other cations (Hardiman \& Jacoby, 1984). In plants, Cd is accumulated mainly in the edible parts, thus making crop yield a potential hazard for human and animal health. It has been suggested that Cadmium may cause damage even at very low concentrations, and healthy plants may contain Cd levels that are toxic for mammals (Chen et al., 2007). Pinot et al. (2000) showed that the main source of Cd accumulation in food is the Cd uptake by plants.

It has been shown that Cadmium can inhibit plant growth and photosynthesis, reduce chlorophyll content, and induce oxidative stress (Schill et al., 2003). In addition, the genotoxicity of $\mathrm{Cd}$ is directly related to its effect on the structure and function of DNA. Therefore, Cd toxicity not increases the mortality rate in the exposed organisms, but may also result in the modification of the population dynamics and the species biological diversity (Theodorakis et al., 2006). Furthermore, it has been shown that cadmium generates oxidative stress through the formation of reactive oxygen species (ROS). The formation of ROS by cadmium suggests that DNA can also be taken into account as a potential target of this metal (Błasiak, 2001).

It has been suggested that proline plays a role in protecting plants from heavy metal toxicity. Siripornadulsil et al. (2002) reported that proline reduces cadmium stress not by sequestering cadmium but by reducing cadmium-induced free radical damage, thus maintaining a more reducing environment in the cell. Xu et al. (2009) found that proline pre-treatment of Solanum nigrum reduces the reactive oxygen species levels and protects the plasma membrane integrity of callus under cadmium stress.

The objectives of this study were to study the effects of $\mathrm{Cd}$ on germination, seedling and callus growth, biochemical properties and DNA fingerprint of in vitro grown C. pumilum.

\section{Materials and Methods}

\subsection{Plant Material, Seed Germination and Proliferation}

Ripe fruits of Cichorium pumilum Jacq were collected from Irbid/Jordan during the summer of 2011. Seeds were surface sterilized with $2 \%$ sodium hypochlorite solution for $10 \mathrm{~min}$, then washed with $70 \%$ ethanol for $30 \mathrm{~s}$, followed by three rinses in sterile distilled water. Seeds were inoculated into Petri dishes containing germination medium of half strength Murashige and Skoog (MS) salts, $2 \%$ sucrose, and $0.8 \%$ Difco-Bacto agar in addition to different levels of $\mathrm{CdCl}_{2}$. Plates were incubated in the dark at $24 \pm 2{ }^{\circ} \mathrm{C}$ for 7 days, and then germination percentages, hypocotyl and root lengths were recorded.

Shoot tips were excised from in vitro grown seedlings and cultured on MS medium supplemented with $1 \mu \mathrm{M}$ Benzyl adenine (BA) and $0.5 \mu \mathrm{M}$ naphthaleneacetic acid (NAA) for shoot proliferation (Al Khateeb et al., 2012). The new microshoots were subcultured after 6 weeks on fresh medium containing different levels of $\mathrm{CdCl}_{2}(50$, $100,200,400,800$, and $1600 \mu \mathrm{M})$. Cultures were placed in a growth chamber $\left(24 \pm 2{ }^{\circ} \mathrm{C}\right.$ and $16 \mathrm{~h}$ light in cool white fluorescent light) for further growth. After 6 weeks, the fresh weights of the shoots were recorded.

\subsection{Callus Growth}

Al Khateeb et al. (2012) protocol was used for callus induction. Three-week-old callus was divided into parts of $0.5 \mathrm{~g}$. Then, these parts were subcultured onto the same medium supplemented with different $\mathrm{CdCl}_{2}$ levels. Cultures were maintained at $24 \pm 2{ }^{\circ} \mathrm{C}$ and $16 \mathrm{~h}$ light in cool white fluorescent light. Fresh weights were taken every week for a period of 6 weeks.

\subsection{Chlorophyll Analysis}

The effect of different concentrations of $\mathrm{Cd}^{2+}$ on chlorophyll content was tested. Microshoots grown on MS medium supplemented with different levels of $\mathrm{CdCl}_{2}$ were extracted with $80 \%$ acetone overnight, the $A_{645}$ and $A_{663}$ were determined using spectrophotometer and chlorophyll content was calculated according to the method of Mackinney (1941).

\subsection{Proline Analysis}

$500 \mathrm{mg}$ of plant tissues from microshoots grown on MS medium supplemented with different levels of $\mathrm{CdCl}_{2}$ were homogenized in $10 \mathrm{~mL}$ of aqueous solution of sulfosalicylic acid. The solution was then filtered rapidly through a Buchner funnel using Whatman filter paper $\mathrm{N}^{\circ} 2.2 \mathrm{~mL}$ of the filtrate was transferred to a test tube in addition to $2 \mathrm{~mL}$ of ninhydric acid and $2 \mathrm{~mL}$ of glacial acetic acid, followed by one hour incubation at $100{ }^{\circ} \mathrm{C}$. The reaction was then stopped in an ice bath. Afterwards, $4 \mathrm{~mL}$ of toluene was added and the contents of the tube 
were inverted for 20 seconds. After this, the toluene phase was separated by centrifugation at $13,000 \mathrm{~g}$ for 10 minutes. Finally, the absorbance was measured at $520 \mathrm{~nm}$ with a visible light spectrophotometer. The concentration of proline was determined from the calibration curve.

\subsection{Lipid Peroxidation}

Lipid peroxidation was estimated based on measuring the malondialdehyde (MDA) content. The MDA content in microshoots grown on MS medium supplemented with different levels of $\mathrm{CdCl}_{2}$ was analyzed following Heath and Packer (1968). This assay is based on the reaction with thiobarbituric acid. Fresh microshoots $(0.5 \mathrm{~g})$ were ground in $20 \mathrm{~mL}$ of $0.1 \%$ tri-chloroacetic acid (w/v) then centrifuged for $15 \mathrm{~min}$ at $13,000 \mathrm{~g}$. One $\mathrm{mL}$ of the supernatant was reacted with $5 \mathrm{~mL}$ of $20 \%$ TCA solution containing $0.5 \%$ thiobarbituric acid (w/v). After that, the mixture was heated for $45 \mathrm{~min}$. at $95{ }^{\circ} \mathrm{C}$ and then cooled immediately in an ice bath. Next, the mixture was centrifuged for $5 \mathrm{~min}$ at $13,000 \mathrm{~g}$, and finally the absorbance of the supernatant was measured using spectrophotometer at 532 and $600 \mathrm{~nm}$. MDA content was calculated using the extinction coefficient of $155 /(\mathrm{mM} / \mathrm{cm})$ (Soltani et al., 2006).

\subsection{DNA Extraction and RAPD Analysis}

DNA was extracted from $C$. pumilum microshoots using modified CTAB (cetyltrimethylammonium bromide) method (Porebski et al., 1997). DNA concentration was measured spectrophotometrically at $260 \mathrm{~nm}$. The RAPD reaction was performed in a total volume of $50 \mu \mathrm{L}$ containing $5 \mu \mathrm{L}$ template DNA, $10 \times$ PCR buffer, $5 \mathrm{mM}$ $\mathrm{MgCl}_{2}, 250 \mu \mathrm{M}$ deoxynucleoside triphosphates, $1.5 \mathrm{U}$ of Taq DNA polymerase and $1 \mu \mathrm{M}$ of each primer. Primers were obtained from commercially available kits (OPA, OPC, and OPG) (Operon Technologies, CA and USA) (Table 1). DNA amplification program in the thermal cycler was as follows; 40 cycles of $94{ }^{\circ} \mathrm{C}$ for 1 min, $52{ }^{\circ} \mathrm{C}$ for $45 \mathrm{sec}$ and $72{ }^{\circ} \mathrm{C}$ for $30 \mathrm{~s}$. A final extension step was also used at $72{ }^{\circ} \mathrm{C}$ for $5 \mathrm{~min}$. PCR products were loaded on agarose gel (1.5\% agarose) and run with Tris-borate-EDTA (TBE) buffer for $90 \mathrm{~min}$.

Table 1. Sequence information of RAPD primers used for C. pumilum fingerprinting

\begin{tabular}{cc}
\hline RAPD Primers & Sequence Information \\
\hline OPC & GTCCCGACGA \\
OPG03 & GAGCCCTCCA \\
OPG05 & CTGAGACGGA \\
PM5 & CGACGCCCTG \\
PM6 & GCGTCGAGGG \\
OPAB 14 & AAGTGCGACC \\
OPO 08 & GCTCCAGTGT \\
OPAH 15 & CTACAGCGAG \\
OPAO 01 & AAGACGACGG \\
OPAP 20 & CCCGGATACA \\
CRC & GCGAACCTCG \\
CRA22 & CCGCAGCCAA \\
\hline
\end{tabular}

\subsection{Statistical Analysis}

Statistical significance was confirmed by analysis of variance (ANOVA) using SPSS for Windows (version 16.0). Results were expressed as mean \pm standard error. Means were separated by using Tukey t-test at 0.05 level of probability. All experiments were repeated at least three times.

\section{Results}

Analysis of variance (ANOVA) showed that cadmium affects germination, hypocotyl and root length, fresh weights of shoots, chlorophyll and proline content, lipid peroxidation level, and callus growth of Cichorium pumilum significantly at 0.05 level of probability. 


\subsection{Effect of Cadmium on Germination Percentage}

In general, the germination percentage of Cichorium pumilum decreased as $\mathrm{Cd}^{2+}$ level increased (Figure 1. A). The highest germination percentage $(100 \%)$ was found in the control. A sharp reduction in germination percentage was observed when the seeds were treated with $50 \mu \mathrm{M} \mathrm{CdCl}_{2}(80 \%)$. No significant differences were observed between 100, 200 and $400 \mu \mathrm{M} \mathrm{CdCl}_{2}$ levels. The lowest germination percentage was observed when $C$. pumilum seeds were treated with the highest $\mathrm{CdCl}_{2}$ concentration $(1600 \mu \mathrm{M})$ which resulted in only $50 \%$ germination.

\subsection{Effect of Cadmium on Hypocotyl and Root Length}

Results show that the hypocotyl length of $C$. pumilum decreased with increasing $\mathrm{CdCl}_{2}$ concentration (Figure 1 . B). No significant difference was observed for hypocotyls length between control and the lowest levels of $\mathrm{CdCl}_{2}$. No significant differences in hypocotyls length was observed between 100, 200, 400 and $800 \mu \mathrm{M} \mathrm{CdCl}_{2}$ levels. Treating C. pumilum seedlings with $1600 \mu \mathrm{M} \mathrm{CdCl}_{2}$ resulted in the highest reduction of the hypocotyls length.

A clear trend for the effect of $\mathrm{CdCl}_{2}$ on root length was observed: root length of $C$. pumilum decreased when increasing $\mathrm{CdCl}_{2}$ concentration (Figure 1 . C\&D). Root length was moderately affected by $50 \mu \mathrm{M} \mathrm{CdCl}_{2}$, while higher levels $(100$ and $200 \mu \mathrm{M})$ decreased root length significantly to $50 \%$ of the control. Furthermore, seedlings grown on $1600 \mu \mathrm{M} \mathrm{CdCl}_{2}$ had the shortest roots.

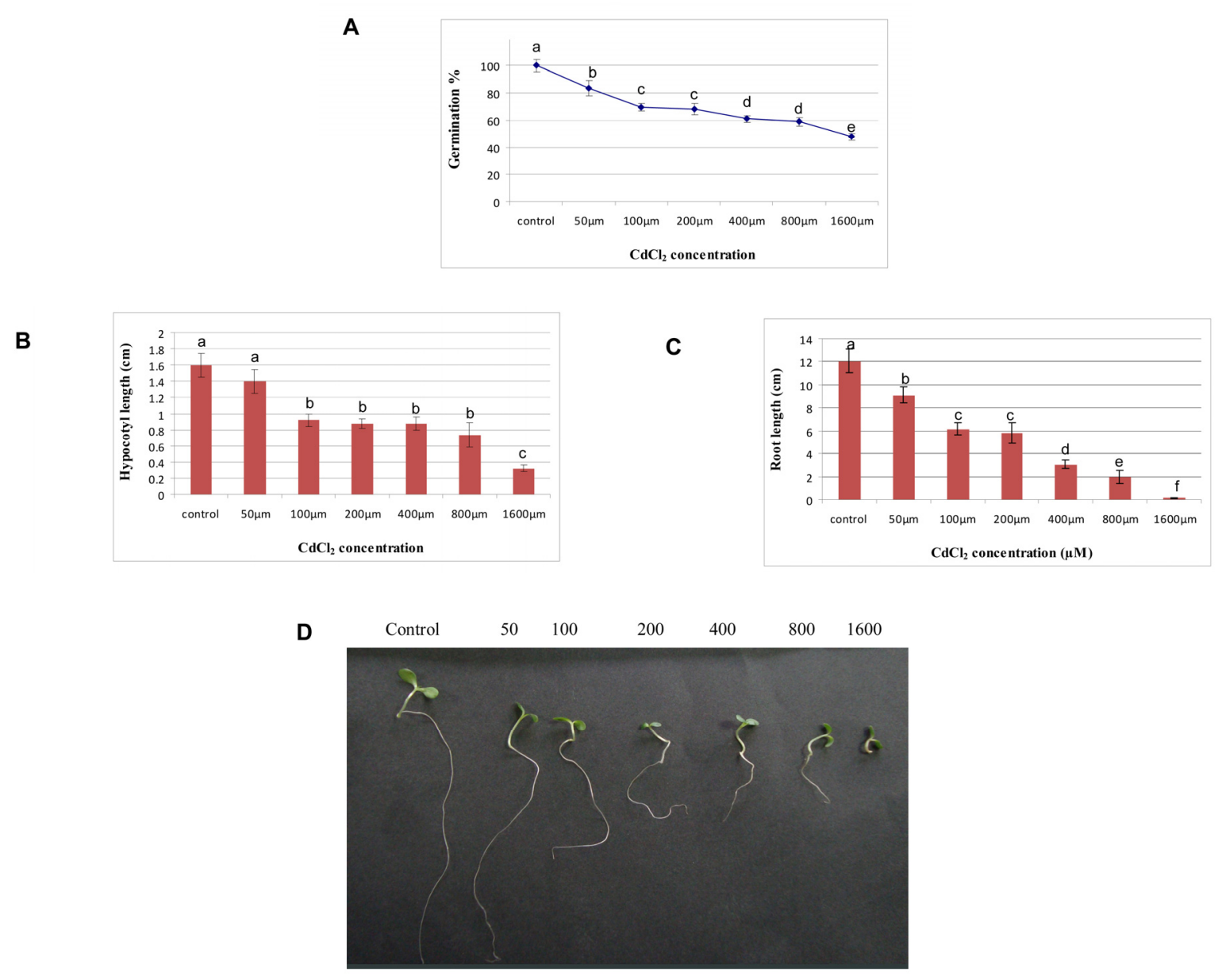

Figure 1. Germination percentage, hypocotyls length and root length of $C$. pumilum grown under different levels of $\mathrm{CdCl}_{2}$. Data represents mean values \pm standard error of ten replicates and the whole experiment was repeated three times. Means followed by the same letter are not statistically different at $\mathrm{p} \leq 0.05$

\subsection{Effect of Cadmium on Shoot Fresh Weight}

Shoot fresh weight of C. pumilum was measured after 6 weeks of in vitro growth under different levels of $\mathrm{CdCl}_{2}$. 
Shoot fresh weight was affected adversely with increasing $\mathrm{CdCl}_{2}$ concentration (Figure 2. A). Microshoots grown on MS medium supplemented with $50 \mu \mathrm{M} \mathrm{CdCl}_{2}$ resulted in a significant reduction in shoot fresh weight with $7.6 \mathrm{~g}$ compared to $8.9 \mathrm{~g}$ in the control. Higher levels of $\mathrm{CdCl}_{2}$ reduced shoot fresh weight severely. No significant difference for shoot fresh weight was observed between 100 and $200 \mu \mathrm{M} \mathrm{CdCl}_{2}$. Sharp significant decreases in shoot fresh weights were observed for C. pumilum exposed to 800 and $1600 \mu \mathrm{M} \mathrm{CdCl}_{2}$ which resulted in more than tenfold reduction compared to the control.

\subsection{Effect of Cadmium on Chlorophyll Content}

Chlorophyll content for C. pumilum microshoots at 50 and $100 \mu \mathrm{M} \mathrm{CdCl}_{2}$ was found to be similar to control microshoots (Figure 2. B). In contrast, microshoots grown in MS medium supplemented with 200, 400, 800 and $1600 \mu \mathrm{M} \mathrm{CdCl}_{2}$ showed higher levels of chlorophyll content than those grown in the control medium and lower levels of $\mathrm{CdCl}_{2}$. No significant differences in chlorophyll content were observed between shoots grown on medium supplemented with 400,800 and $1600 \mu \mathrm{M} \mathrm{CdCl}_{2}$.

A

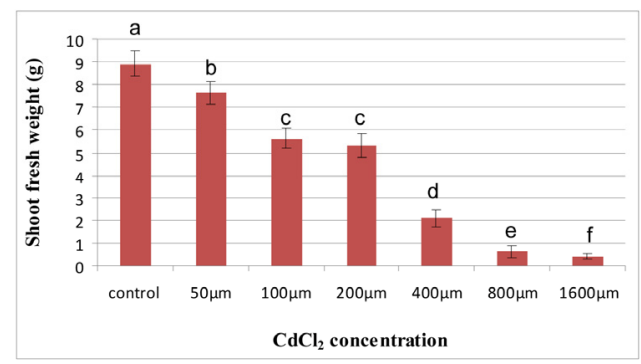

B

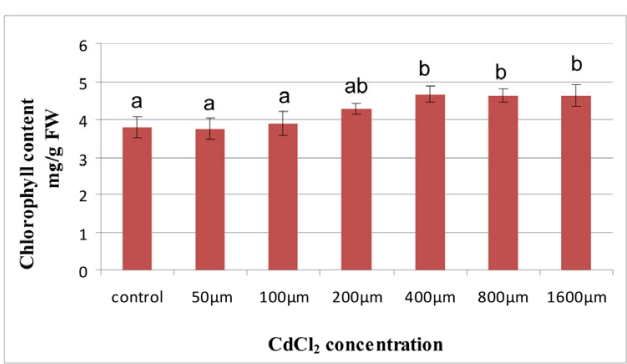

Figure 2. Shoot fresh weight and chlorophyll content of in vitro grown C. pumilum under different levels of $\mathrm{CdCl}_{2}$. Data represents mean values \pm standard error of eight replicates and the whole experiment was repeated three times. Means followed by the same letter are not statistically different at $p \leq 0.05$

\subsection{Effect of Cadmium on Callus Growth}

Different callus growth rates were observed based on fresh weight gain between the different levels of $\mathrm{CdCl}_{2}$ (Figure 3). Calli grown on control medium showed the highest growth rate during the six weeks reaching a final fresh weight of $11.3 \mathrm{~g}$. On the other hand, calli grown on MS medium supplemented with $50 \mu \mathrm{M} \mathrm{CdCl}_{2}$ showed growth inhibition compared with the control and resulted in a final fresh weight of only $3.2 \mathrm{~g}$. Calli grown on medium supplemented with $100 \mu \mathrm{M} \mathrm{CdCl}_{2}$ showed more inhibition than that grown on $50 \mu \mathrm{M} \mathrm{CdCl}_{2}$. Higher levels of $\mathrm{CdCl}_{2}$ appear to be lethal for callus growth. 


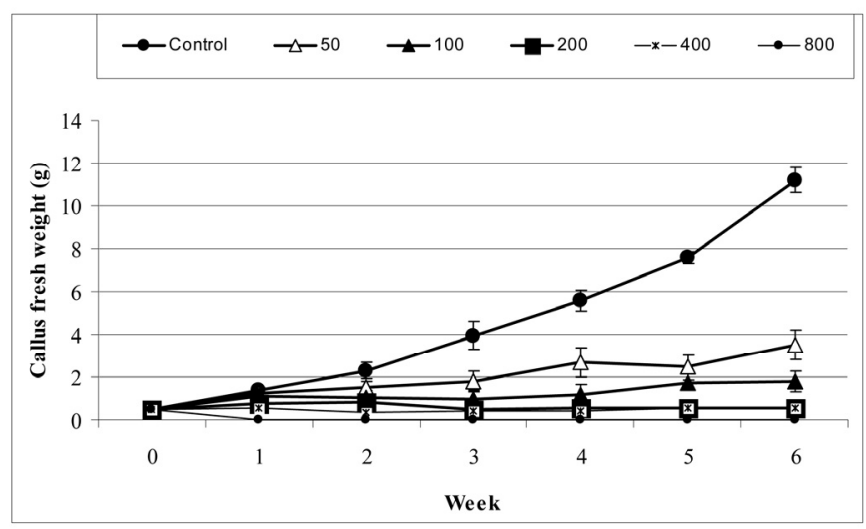

Figure 3. Callus growth curve of of C. pumilum grown under different levels of $\mathrm{CdCl}_{2}$. Data represents mean values \pm standard error of ten replicates and the whole experiment was repeated three times

\subsection{Effect of Cadmium on Proline and Lipid Peroxidation Level}

Proline content for C. pumilum microshoots was examined under different levels of $\mathrm{CdCl}_{2}$. Results showed that proline content increased gradually and significantly as $\mathrm{CdCl}_{2}$ level increased in the growth medium (Figure 4 . A). The highest proline content was obtained from microshoots grown on the MS medium supplemented with the highest level of $\mathrm{CdCl}_{2}(400 \mu \mathrm{M})$. Results showed that growing microshoots on $400 \mu \mathrm{M} \mathrm{CdCl}_{2}$ increased proline content by more than tenfold.

The influence of $\mathrm{Cd}^{2+}$ on the lipid peroxidation rate of C. pumilum shoots was estimated by measuring MDA content, which is the product of lipid peroxidation. Lipid peroxidation rate in C. pumilum microshoots increased with increasing $\mathrm{CdCl}_{2}$ level (Figure 4. B). Growing microshoots on MS medium supplemented with $50 \mu \mathrm{M}$ $\mathrm{CdCl}_{2}$ enhanced lipid peroxidation rate by more than twofold (compared with control). The highest lipid peroxidation rate was achieved in microshoots grown in MS medium supplemented with $400 \mu \mathrm{M} \mathrm{CdCl}_{2}$.

A

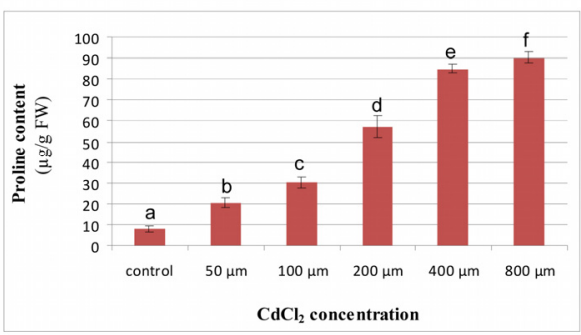

B

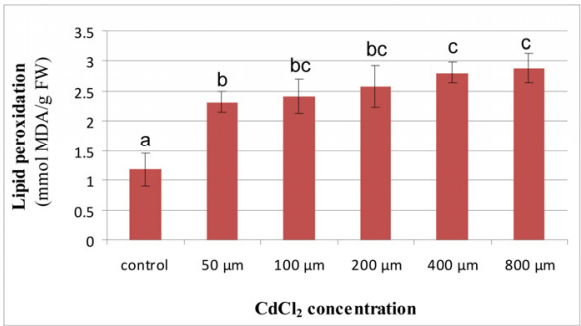

Figure 4. Proline content and lipid peroxidation rate of C. pumilum microshoots grown under different levels of $\mathrm{CdCl}_{2}$ Data represents mean values \pm standard error of eight replicates and the whole experiment was repeated three times. Means followed by the same letter are not statistically different at $p \leq 0.05$

\subsection{DNA Fingerprinting Using RAPD Analysis}

Genomic DNA was extracted from plants grown for 4 weeks on MS medium supplemented with different levels 
of $\mathrm{Cd}^{2+}$. Twelve primers were used in this experiment (Table 1). Amplified profiles resulting from these primers showed variation between untreated and treated plants in terms of number and size of DNA bands. Figureure 5 shows RAPD profiles of treated and untreated samples of $C$. pumilum microshoots obtained from primer OPAP 20 as a representative for the other primers. The RAPD profiles obtained showed bands between 300 and 1800 $\mathrm{bp}$ in length. A total of 184 bands scored, only 36 were found to be polymorphic. Figure 5 shows the appearance or absence of bands at 200 and $400 \mu \mathrm{M} \mathrm{CdCl}_{2}$.

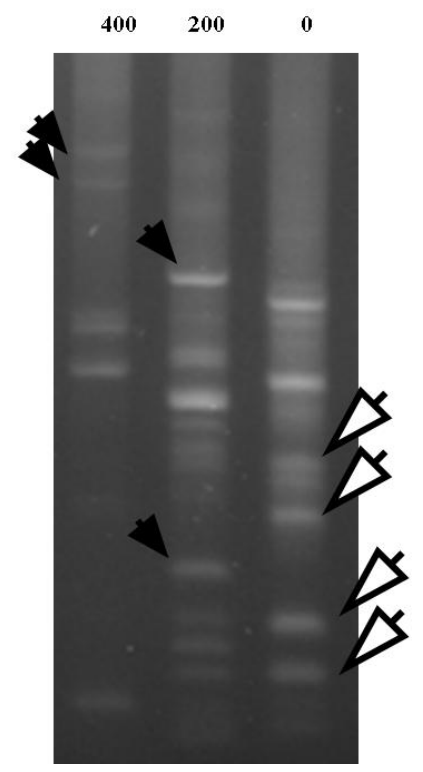

Figure 5. RAPD profiles (using primer OPAP 20) of genomic DNA extracted from C. pumilum microshoots grown under 0,200 and $400 \mu \mathrm{M} \mathrm{CdCl}_{2}$. Black arrows represent appearance of new bands and white arrows represent absence of bands relative to control (0)

\section{Discussion}

Plant growth and development under stress conditions are generally negatively affected. One of these stress conditions that affect plants is heavy metals. Recently, heavy metals have become a hot topic of research for many researchers around the world, mostly due to their detrimental effects on many organisms including plants.

Much research has been conducted on the effect of $\mathrm{Cd}^{2+}$ on crops and other agricultural plants. However, little information is available on the toxicity of $\mathrm{Cd}^{2+}$ on medicinal plants. Thus, the aim of this study was to assess the effect of cadmium on germination, growth, proline content, lipid peroxidation, and DNA fingerprinting of in vitro grown $C$. pumilum. Here, in vitro culture was used which is a convenient system for the study of mechanism of metal toxicity, as it eliminates the interfering processes of translocation and organ-specific trapping of metal ions.

The results of this study showed that $\mathrm{Cd}^{2+}$ levels affected all of the studied parameters in C. pumilum by different magnitudes. A significant reduction in percentages of seed germination, hypocotyl and root lengths of $C$. pumilum was observed here. This is in agreement with many published reports that studied the effects of $\mathrm{Cd}^{2+}$ on other plant species. Mathur et al. (1987) found that higher levels of cadmium inhibited germination percentage and the growth of the early seedlings of Allium cepa. Similarly, He et al. (2008) found that cadmium stress significantly inhibits germination index and shoot and root growth of rice. Pasquale et al. (1995) studied the influence of cadmium on the growth and biological activity of the medicinal plant Coriandrum sativum L. They found that growing plants under cadmium stress significantly reduced shoot and root lengths, resulting in leaf yellowing and in a major alteration in the essential oil quality and quantity. It has been shown that cadmium stress causes many problems in plants including growth and photosynthesis inhibition, alteration in nutrients and formation of free radicals (Sahu et al., 2007). Seed germination reduction due to heavy metals stress could be attributed to higher levels of seeds stored nutrients breakdown and/or change in permeability characteristics of the cell membrane (Shafiq et al., 2008). In peanuts, it has been shown that root and shoot growth and the initiation of lateral roots decreased with the increase in cadmium levels (Renjini \& Janardhanan, 1989). The 
reason for reduced seedling length in metal treatments could be due to the reduction in meristematic cells present in this region and of some enzymes contained in the cotyledon and endosperms.

It has been shown that another species of Chicory (Cichorium intybus L.) showed a potential to be used as heavy metal bioindicator, $C$. intybus plants grown in nutrient solution supplemented with $0.5-50 \mu \mathrm{M}$ cadmium showed high levels of Cd, in their shoots and roots (Simon et al., 1996). Another study (Kostantinos et al., 2008) showed that the fresh and dry weights of Cichorium endivia L. were not affected when grown on soil supplemented with different levels of Cd. Furthermore, they found that no toxicity symptoms were observed on Cichorium endivia plants.

Moreover, the result of this study showed that $\mathrm{Cd}^{2+}$ treatment significantly increased proline accumulation in $C$. pumilum. Proline accumulation is used as an indicator of stress conditions, including heavy metals. It has been shown that proline acts as a $\mathrm{Cd}^{2+}$ chelator in plants and forms a non-toxic complex with $\mathrm{Cd}^{2+}$ (Sharma et al., 1998). Similarly, Dinakar et al. (2009) found that proline content increased under cadmium stress in Arachis hypogaea $\mathrm{L}$. It has been shown that plants subjected to $\mathrm{CdSO}_{4}$ stress in the presence of proline showed a lower amount of reactive oxygen species compared to plants without proline. (Xu et al., 2009).

In addition to proline accumulation, the amount of lipid peroxidation also increased in response to $\mathrm{Cd}^{2+}$ stress. This is in agreement with Shah et al. (2001) who found an increase in malondialdehyde (MDA) levels (enhancement of lipid peroxidation) in rice seedlings after $\mathrm{Cd}\left(\mathrm{NO}_{3}\right)_{2}$ exposure. Similarly, Soltani et al. (2006) found that cadmium stress increased lipid peroxidation levels in Brassica napus plants. Lipid peroxidation is the main sign of free radical elevation. Plants may have two classes of antioxidative systems against the perceived oxidative stress: enzymatic antioxidants (such as superoxide dismutase (SOD)) and non-enzymatic low molecular weight antioxidants (such as proline, ascorbic acid, and glutathione) that can directly detoxify free oxygen radicals.

Different classical genotoxic assays have been used to examine the effect of heavy metals on plants including the comet assay and the micronucleus assay (Cambier et al., 2010). Recently, DNA fingerprinting has been successfully applied to test the effect of such stresses at the molecular level in different species (Korpe \& Aras, 2011; Liu et al., 2012). The ability of cadmium to induce DNA mutations and/or damage has been shown previously (Gichner et al., 2004; Liu et al., 2012). Insertions and deletions, point mutations, base substitutions, single/double-strand breaks are examples of the effect of cadmium stress on DNA (Castano \& Becerril, 2004). Here, RAPD profile shows different changes in the DNA fingerprint indicating that $\mathrm{Cd}^{2+}$ affects the genome integrity. Not all primers showed variations in the RAPD profile between treated and non-treated plants, which could be explained by the variation in genome sensitivity to heavy metals stress between different regions. Also, some genome areas could be protected from external damage (Liu et al., 2012).

In conclusion, the results of this study showed that $\mathrm{Cd}^{2+}$ had a toxic effect on germination, growth, proline content, lipid peroxidation, and DNA fingerprinting of in vitro grown C. pumilum. A reduction in hypocotyl and root length and shoot fresh weight was observed in seedlings grown under $\mathrm{Cd}^{2+}$ stress. A gradual increase in proline content and lipid peroxidation along with increasing $\mathrm{Cd}^{2+}$ concentration was also observed. The variation that occurred in the RAPD profiles of microshoots following $\mathrm{Cd}^{2+}$ treatment can be efficiently used as a sensitive tool to detect DNA damage and genotoxicity.

\section{Acknowledgements}

This work was supported by the deanship of research at Yarmouk University (Project \#22/2009).

\section{References}

Al Khateeb, W., Hussein, E., Qouta, L., Alu'datt, M., Al-Shara, B., \& Abu-zaiton, A. (2012). In vitro propagation and characterization of phenolic content along with antioxidant and antimicrobial activities of Cichorium pumilum Jacq. Plant Cell, Tissue and Organ Culture, 110(1), 103-110. http://dx.doi.org/10.1007/s11240-012-0134-9

Benavides, M., Gallego, S., \& Tomaro, M. (2005). Cadmium toxicity in plants. Braz. J. Plant Physiol, 17, 21-34. http://dx.doi.org/10.1590/S1677-04202005000100003

Błasiak, J. (2001). DNA-Damaging effect of Cadmium and protective action of Quercetin. Polish Journal of Environmental Studies, 10, 437-442.

Castano, A., \& Becerril, C. (2004). In vitro assessment of DNA damage after short- and long-term exposure to benzo(a)pyrene using RAPD and the RTG-2 fish cell line. Mutat. Res., 552, 141-151. http://dx.doi.org/10.1016/j.mrfmmm.2004.06.010 
Chen, F., Dong, J., Wang, F., Wu, F., Zhang, G., Li, G., ... Wei, K. (2007). Identification of barley genotypes with low grain $\mathrm{Cd}$ accumulation and its interaction with four microelements. Chemosphere., 67, 2082-2088. http://dx.doi.org/10.1016/j.chemosphere.2006.10.014

Dinakar, N., Nagajyothi, P. C., Suresh, S., Damodharan, T., \& Suresh, C. (2009). Cadmium induced changes on proline, antioxidant enzymes, nitrate and nitrite reductases in Arachis hypogaea L. J. Environ. Biol., 30(2), 289-294.

Gichner, T., Patková, Z., Száková, J., \& Demnerová, K. (2004). Cadmium induces DNA damage in tobacco roots, but no DNA damage, somatic mutations or homologous recombination in tobacco leaves. Mutat. Res., 559, 49-57. http://dx.doi.org/10.1016/j.mrgentox.2003.12.008

Gratão, P., Polle, A., Lea, P., \& Azevedo, R. (2005). Making the life of heavy metal-stressed plants a little easier. Funct. Plant Biol., 32, 481-494. http://dx.doi.org/10.1071/FP05016

Hardiman, R., \& Jacoby, B. (1984). Absorption and translocation of Cd in bush beans in the environment: sources, mechanisms of biotoxicity, and biomarkers. Rev. Environ. Health., 15, 299-323.

He, J., Yan-fang, R., Cheng, Z., \& De-an, J. (2008). Effects of Cadmium Stress on Seed Germination, Seedling Growth and Seed Amylase Activities in Rice (Oryza sativa) Rice Science., 15(4), 319-325. http://dx.doi.org/10.1016/S1672-6308(09)60010-X

Heath, R., \& Packer, L. (1968). Photoperoxidation in isolated chloroplasts. I. Kinetics and stoichiometry of fatty acid peroxidation. Arch. Biochem. Biophys., 125, 189-198. http://dx.doi.org/10.1016/0003-9861(68)90654-1

Iribar, V., Izco, F., Tames, P., Antiguedad, I., \& da Silva, A. (2000). Water contamination and remedial measures at the Troya abandoned Pb-Zn mine (The Basque Country, Northern Spain). Environ. Geol., 39, 800-806. http://dx.doi.org/10.1007/s002540050496

Kidd, S., Domínguez-Rodríguez, J., Díez, J., \& Monterroso, C. (2007). Bioavailability and plant accumulation of heavy metals and phosphorus in agricultural soils amended by long-term application of sewage sludge. Chemosphere., 66, 1458-1467. http://dx.doi.org/10.1016/j.chemosphere.2006.09.007

Korpe, A., \& Aras, S. (2011). Evaluation of copper-induced stress on eggplant (Solanum melongena L.) seedlings at the molecular and population levels by use of various biomarkers. Mutat. Res., 719, 29-34. http://dx.doi.org/10.1016/j.mrgentox.2010.10.003

Kostantinos, A., Akoumianakis, \& Harold, C. (2008). Effect of cadmium on yield and cadmium concentration in the edible tissues of endive (Cichorium endivia L.) and rocket (Eruca sativa Mill.). Food, Agriculture and Environment, 6, 206-209. http://dx.doi.org/10.1016/j.mrgentox.2010.10.003

Liu, W., Sun, L., Zhong, M., Zhou, Q., Gong, Z., Li, P., ... Li, X. (2012). Cadmium-induced DNA damage and mutations in Arabidopsis plantlet shoots identified by DNA fingerprinting. Chemosphere., 89, 1048-1055. http://dx.doi.org/10.1016/j.chemosphere.2012.05.068

Mackinney, G. (1941). Absorption of light by chlorophyll solution. J. Biol. Chem., 140, 315-322.

Mathur, K., Srivastava, R., \& Chaudhary, K. (1987). Effect of Cd and Cr metals on germination and early growth performance of Allium cepa seeds. Proc. Nat. Acad. Sci. India. Sect. B (Biol. Sci.)., 57, 191-196.

Nriagu, J. (1990). Global metal pollution. Poisoning the biosphere. Environment., 32, 28-33. http://dx.doi.org/10.1080/00139157.1990.9929037

Pasquale, R., \& Rapisarda, A. (1995). Effects of cadmium on growth and pharmacologically active constituents of the medicinal plant Coriandrum sativum L. Air. Soil. Pollut., 84, 147-157. http://dx.doi.org/10.1007/BF00479594

Pinot, F., Kreps, S., Bachelet, M., Hainaut, P., Bakonyi, M., \& Polla, B. (2000). Cadmium in the environment: sources, mechanisms of biotoxicity, and biomarkers. Rev. Environ. Health., 15, 299-323. http://dx.doi.org/10.1515/REVEH.2000.15.3.299

Porebski, S., Bailey, G., \& Baum, B. (1997). Modification of a CTAB DNA extraction protocol for plants containing high polysaccharide and polyphenol components. Plant Molecular Biology Reporter, 15, 8-15. http://dx.doi.org/10.1007/BF02772108

Renjini, M. B. J., \& Janardhanan, K. (1989). Effect of heavy metals on seed germination and early seedlings growth of groundnut, sunflower and gingerly. Geobios., 16, 164-170. 
Robert, C., Happi Emaga, T., Wathelet, B., \& Paquot, M. (2008). Effect of variety and harvest date on pectin extracted from chicory roots (Cichorium intybus L.). Food Chemistry., 108, 1008-1018. http://dx.doi.org/10.1016/j.foodchem.2007.12.013

Romero-Puertas, M., McCarthy, I., Sandalio, M., Palma, M., Corpas, J., Gómez, M., \& del Río, A. (1999). Cadmium toxicity and oxidative metabolism of pea leaf peroxisomes. Free Radical. Res., 31, 25-31. http://dx.doi.org/10.1080/10715769900301281

Sahu, R. K., Katiyar, S., Tiwari, J., \& Kisku, G. (2007). Assessment of drain water receiving effluent from tanneries and its impact on soil and plants with particular emphasis on bioaccumulation of heavy metals. $J$. Environ. Biol., 28, 685-690.

Schill, O., Gorlitz, H., \& Kohler, H. (2003). Laboratory simulation of a mining accident: acute toxicity, hsc/hsp70 response, and recovery from stress in Gammarus fossarum (Crustacea smphipoda) exposed to a pulse of cadmium. BioMetals., 16, 391-401. http://dx.doi.org/10.1023/A:1022534326034

Sebastiani, L., Scebba, F., \& Tognetti, R. (2004). Heavy metal accumulation and growth responses in poplar clones Eridano (Populus deltoides $\times$ maximowiczii) and I-214 $(P . \times$ euramericana) exposed to industrial waste. Env. Exp. Bot., 52, 79-84. http://dx.doi.org/10.1016/j.envexpbot.2004.01.003

Shafiq, M., Iqbal, M. Z., \& Athar, M. (2008). Effect of lead and cadmium on germination and seedling growth of Leucaena leucocephala. J. Appl. Sci. Environ. Manage., 12(2), 61- 66.

Shah, K., Ritambhara, G., Verma, S., \& Dubey, R. (2001). Effect of cadmium on lipid peroxidation, superoxide anion generation and activities of antioxidant enzymes in growing rice seedlings. Plant Science., 161(6), 1135-1144. http://dx.doi.org/10.1016/S0168-9452(01)00517-9

Sharma, S., Schat, H., \& Vooijs, R. (1998). In vitro alleviation of heavy metal-induced enzyme inhibition by proline. Phytochemistry., 46, 1531-1535. http://dx.doi.org/10.1016/S0031-9422(98)00282-9

Shrivastava, G., \& Singh, P. (1989). Uptake, accumulation and translocation of cadmium and zink in Abelmoschus. Plant Physiol Biochem., 16, 17-22.

Simon, L., Martin, H., \& Adriano, D. (1996). Chicory (Cichorium intybus L.) and dandelion (Taraxacum officinale Web.) as phytoindicators of cadmium contamination. Water, Air, and Soil Pollution. 91, 351-362. http://dx.doi.org/10.1007/BF00666269

Siripornadulsil, S., Traina, S., Verma, D., \& Sayre, R. (2002). Molecular mechanisms of proline-mediated tolerance to toxic heavy metals in transgenic microalgae. Plant Cell., 14, 2837-2847. http://dx.doi.org/10.1105/tpc.004853

Soltani, F., Lagha, G., \& Kalantari, M. (2006). Effect of cadmium on photosynthetic pigments, sugars and malondealdehyde content in (Brassica napus L.). Iranian Journal of Biology, 19(2), 136-145.

Theodorakis, C., Lee, K., Adams, S., \& Law, C. (2006). Evidence of altered gene flow, mutation rate, and genetic diversity in redbreast sunfish from a pulpmill-contaminated river. Environ. Sci. Technol., 40, 377-386. http://dx.doi.org/10.1021/es052095g

Xu, J., Yin, H., \& Li, X. (2009). Protective effects of proline against cadmium toxicity in micropropagated hyperaccumulator, Solanum nigrum L. Plant Cell Rep., 28(2), 325-333. http://dx.doi.org/10.1007/s00299-008-0643-5

\section{Copyrights}

Copyright for this article is retained by the author(s), with first publication rights granted to the journal.

This is an open-access article distributed under the terms and conditions of the Creative Commons Attribution license (http://creativecommons.org/licenses/by/3.0/). 